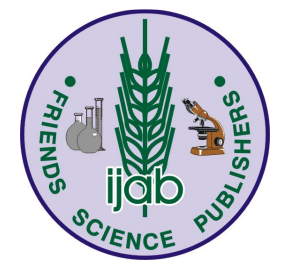

\title{
Bicultures of Oat (Avena sativa) and Grazing Vetch (Vicia dasycarpa) Regulate Residue Decomposition, Nitrogen and Phosphorus Dynamics, and Weed Suppression in Maize
}

\author{
Lindah Muzangwa ${ }^{1}$, Cornelius Chiduza $^{1^{*}}$ and Pardon Muchaonyerwa ${ }^{2}$ \\ ${ }^{1}$ Department of Agronomy, Faculty of Science and Agriculture, University of Fort Hare, P. Bag X1314, Alice 5700, South \\ Africa \\ ${ }^{2}$ School of Agricultural, Earth and Environmental Sciences, University of KwaZulu Natal P. Bag X01, Scottsville 3209, South \\ Africa
}

*For correspondence: cchiduza@ufh.ac.za

\begin{abstract}
Oat (Avena sativa L.) and grazing vetch (Vicia dasycarpa L.) were identified as best bet cover crops in the central Eastern Cape, South Africa, but information on biomass yield, residue decomposition and soil fertility contribution was lacking. This experiment evaluated combinations of $90 \%$ oat $+10 \%$ vetch, $70 \%$ oat $+30 \%$ vetch, $50 \%$ oat $+50 \%$ vetch, $100 \%$ vetch, $100 \%$ oat and a control with no cover crop laid in a randomised complete block design in 2009 and 2010 winter seasons. A follow-on maize crop was planted in the summer seasons of 2010 and 2011. Season $\times$ cover crop interaction was significant $(p<0.001)$ with respect to cover crop biomass. In $2009,90 \%$ oat $+10 \%$ vetch had similar biomass to sole oat whilst in 2010 , $70 \%$ oat $+30 \%$ vetch and $90 \%$ oat $+10 \%$ vetch had similar yield to sole oat. Oat-vetch biculture residues had intermediate $\mathrm{C}: \mathrm{N}$ ratios and decomposition rates compared to sole crops. Sole vetch had the highest soil $\mathrm{N}$ and $\mathrm{P}$ at maize planting but bicultures resulted in higher soil $\mathrm{N}$ and $\mathrm{P}$ during the late maize growing season. The maize in these plots had higher $\mathrm{N}$ and $\mathrm{P}$ uptake. Biculturing significantly $(p<0.05)$ increased maize grain yield compared to sole oat but did not differ $(p>0.05)$ with sole vetch. The findings suggest that bicultures of oat and vetch regulated the decomposition rates and availability of soil nutrients for extended periods for better maize nutrition and grain yield compared to their sole crops. (C) 2015 Friends Science Publishers
\end{abstract}

Keywords: Conservation agriculture; Cover crops; Maize yield; Persistence; Rotation

\section{Introduction}

Soil degradation is a major limiting factor for achieving high crop productivity on most smallholder farms in the central Eastern Cape, South Africa (SA). Conservation agriculture (CA) which involves minimal or no soil disturbance, diversified and ecologically viable crop rotations and permanent soil cover (FAO, 2008) is viewed as a sustainable way of restoring agricultural productivity. However, low crop productivity levels resulting in part from low soil nitrogen $(\mathrm{N})$ and phosphorus $(\mathrm{P})$ in the soils (Mandiringana et al., 2005) has meant that the levels of biomass produced and cover provided are insufficient for purposes of mulching to control weeds and conserve soil moisture. As a result, increasing weed pressure under smallholder CA systems has been observed to be a major challenge impeding the successful adoption of CA by smallholder farmers in SA (Derpsch, 2003) and southern Africa (Giller et al., 2009).

The use of inorganic fertilizer and herbicide technology on smallholder farms in SA is low and opportunistic as these are deemed expensive for the mostly resource poor farmers (Fanadzo et al., 2009). Cover crops that can address both the weed problem and the inherent low soil $\mathrm{N}$ and $\mathrm{P}$ could make significant contribution to improving productivity of maize (Zea mays L.), the staple crop, and be more acceptable to smallholder farmers. Previous work by Murungu et al. (2010) identified grazing vetch (Vicia dasycarpa L.) and oat (Avena sativa L.) as best bet candidate cover crops suitable for maize-based cropping systems in the central Eastern Cape, South Africa. Grazing vetch's ability to fix $\mathrm{N}$, resulting in increased yields of succeeding crops, compared to grass or no cover crop, has been acknowledged by other researchers (Crandall et al., 2005). Subsequent crops can benefit 30 to $60 \%$ of the $N$ fixed by legumes (Kuo et al., 1996).

However, legumes like grazing vetch are associated with low $\mathrm{C}: \mathrm{N}$ ratios which fall far below the critical level for net mineralization, resulting in faster breakdown of their residues. As a result of the fast residue breakdown by

To cite this paper: Muzangwa, L., C. Chiduza and P. Muchaonyerwa, 2015. Bicultures of oat (Avena sativa) and grazing vetch (Vicia dasycarpa) regulate nitrogen and phosphorus dynamics, and weed suppression in Maize. Int. J. Agric. Biol., 17: 475-482 
legumes, high levels of inorganic $\mathrm{N}$ and $\mathrm{P}$ are released earlier and faster compared to a grass cover crop (Ruffo and Bollero, 2003; Sainju et al., 2005). The rapid rates of mineralization may result in loss of plant available $\mathrm{N}$ through leaching if not well synchronized with the demand by a follow-on crop. Furthermore, the weed control by residues of these legumes can be compromised owing to the lack of persistence of soil cover. Whereas grass cover crops do not fix $\mathrm{N}$, they can scavenge for residual and leached nutrients due to deep rooting system (Ruffo and Bollero, 2003). The breakdown and release of the assimilated nutrients by grass cover crops is slow because of the high $\mathrm{C}: \mathrm{N}$ ratios associated with their residues (Rosecrance et al., 2000). The C:N ratio has been accepted as a general index of quality of crop residues (Nicolardot et al., 2001). Due to their persistence and slow degradation, grass residues are able to smoother weeds for a longer period as well as contributing to build up of different soil organic matter pools. Different mechanisms operate to account for weed control and not just biomass and persistence when using cover crops. Biomass $\mathrm{N}$ content, allelochemicals and root exudates all interact and contribute in determining weed density and species (Jordan et al., 2000; Kumar et al., 2008). As mixtures of grass and legume vary in biculture, it can be expected that there will be varying effects on weeds.

Scientific evidence suggests that the practice of planting a legume cover crop with a grass cover crop (biculturing) could be a management option to maximise cover cropping benefits. Studies by Sainju et al. (2005) and Dabney et al. (2010) noted improved above ground biomass yields, with optimum $\mathrm{C}: \mathrm{N}$ ratios resulting in moderate residue degradation as a result of biculturing legumes and grass crops. Moderate residue degradation leads to moderate biomass persistence and mineralization rates translating to weed control and soil nutrient availability for longer periods (Ranells and Wagger, 1996; Clark et al., 1997; Teasdale et al., 2007). However, some studies have demonstrated that legumes grown in biculture with grasses typically have total residue C:N ratios above 25 (Starovoytov et al., 2010) and would release $\mathrm{N}$ more slowly. Therefore, the proportion of grass and legume in the biculture is important to realise moderate residue degradation and synergistic benefits of grass and legume cover crops to address soil fertility and weed constraints in the central Eastern Cape and similar smallholder environments in southern Africa.

Biculturing modifies the biochemical make up of both the grass and legume and their interaction in the decomposition of the residues. The knowledge about the dynamics of decomposition of residues that are mixtures of legumes and grasses is essential for the development of sustainable maize-based smallholder cropping systems in southern Africa. Therefore, the objective of this work was to evaluate the decomposition of oat-vetch biculture residues in comparison to their sole residues and the resultant effect on $\mathrm{N}$ and $\mathrm{P}$ fertility and weed suppression in follow-on irrigated maize.

\section{Materials and Methods}

\section{Study site}

The study was carried out at the University of Fort Hare Research Farm, South Africa $\left(32^{\circ} 47^{\prime} \mathrm{S}\right.$ and $\left.27^{\circ} 50^{\prime} \mathrm{E}\right)$. The farm is at an altitude of $508 \mathrm{~m}$ above sea level and has a moderate climate with an average annual rainfall of $575 \mathrm{~mm}$ and an annual mean temperature of $18^{\circ} \mathrm{C}$. The soil is of the Ritchie family of the Oakleaf form (Soil Classification Working Group, 1991) and a Eutric Cambisol according to the World Reference Base for Soil Resources (WRB) system (IUSS Working Group, 2006). The soil at the initiation of the experiment had a $\mathrm{pH}$ of 5.9 (water), an electrical conductivity of $0.14 \mathrm{dS} \mathrm{m}^{-1}$ and total $\mathrm{C}$ and $\mathrm{N}$ was 1.1 and $0.087 \%$, respectively and inorganic $\mathrm{P}$ was $2.01 \mathrm{mg}$ $\mathrm{kg}^{-1}$. The soil contained $64.2 \%$ sand, $16.0 \%$ silt and $19.8 \%$ clay (Mandiringana et al., 2005).

\section{Cover Cropping}

The trial site was ploughed, disked and rotovated to make a fine tilth before the initial cover crop establishment in the winter of 2009. Thereafter all plantings were done under no-till. Grazing vetch (V. dasycarpa var. Max) and white oat (A. sativa var. Pallinup) cover crops were grown as bicultures at three ratios and as monocultures in the winter seasons of 2009 and 2010. Treatments were $90 \%$ oat + $10 \%$ vetch, $70 \%$ oat $+30 \%$ vetch, $50 \%$ oat $+50 \%$ vetch, $100 \%$ oat, $100 \%$ vetch (where $\%$ refers to the percentage of the recommended seeding rate used in the monoculture). The recommended rates were 100 and $50 \mathrm{~kg} \mathrm{ha}^{-1}$ for oat and vetch, respectively (Murungu et al., 2011). A weedy fallow treatment was included as a control. The experiment was laid out in a Randomized Complete Block Design (RCBD) with three replicates. The plot sizes measured 6 $\mathrm{m} \times 5 \mathrm{~m}$.

Vetch was inoculated with Rhizobium leguminosarium bio var viciae inoculant having $5 \times 10^{8}$ rhizobial cells g ${ }^{-1}$ (Stimuplant CC, Zwavelpoort 0036, SA), at planting. Only basal compound fertilizer with an N: P: K ratio of $2: 3: 4(30)+0.5 \% \mathrm{Zn}$ was applied at planting to supply $13.3 \mathrm{~kg} \mathrm{~N} \mathrm{ha}^{-1}, 20 \mathrm{~kg} \mathrm{P} \mathrm{ha}^{-1}$ and $26.7 \mathrm{~kg} \mathrm{~K} \mathrm{ha}^{-1}$, to all cover crop treatments. Neither weed nor pest control was done during the growth of the cover crops. The cover crops were grown under irrigation as outlined in Muzangwa et al. (2012). Cover crop growth was terminated at the flowering stage by the application of Glyphosate herbicide ( $3 \mathrm{~L} \mathrm{ha}^{-1}$ ) followed by rolling with a tractor-drawn roller. Two randomly thrown $0.35 \mathrm{~m} \times 0.35$ $\mathrm{m}$ quadrants were used for destructive sampling of cover crops and weeds per plot. All cover crop and weed biomass present within the quadrant were cut at ground level and dried at $65^{\circ} \mathrm{C}$ to constant weight to obtain the biomass input. 


\section{Cover Crop Residue Decomposition}

The biculture residue samples were not separated according to cover crop species. A sub-sample of the plant materials was ground $(<1 \mathrm{~mm})$ and analysed for total $\mathrm{C}$ and $\mathrm{N}$ content using the LECO C/N analyser (LECO Corporation, 2003). For each treatment, 10 litterbag bags were filled with $10 \mathrm{~g}$ of oven dried biomass material. The litterbags were $0.20 \times 0.20$ $\mathrm{m}$ in size made out of a nylon mesh with $1 \mathrm{~mm}$ pores. On the day of cover crop growth termination, the litterbags were placed on the soil surface of corresponding plots from which the residues were produced. The litterbags and the plant residues in the plots were rolled on to create a firm contact for maximum influence of meso- and macro-fauna.

Litterbags were sampled by removing one litterbag from each plot fortnightly for a period of 18 weeks. Nondecomposed material was carefully separated from the litterbags and roots and soil particles were removed. The samples were oven dried to constant mass at $65^{\circ} \mathrm{C}$ to determine mass remaining. The effects of soil adhering to plant materials were discounted by ashing samples in a muffle furnace at $450^{\circ} \mathrm{C}$ for $5 \mathrm{~h}$. Ash free dry weight (AFDW) was determined by subtracting the ash content from the dry weight. Negative exponential regression was used to calculate the decomposition coefficient $k$ as shown in the equation below.

$$
\mathrm{Y}=\mathrm{A}^{-\mathrm{k} x}
$$

(Olsen, 1963)

Where, $\mathrm{Y}$ represents the residue remaining as a percentage of the initial weight, $\mathrm{A}$ is the initial residue weight at initiation of the litterbag study in grams and $x$ being the time of exposure of the litterbags in the field measured in weeks.

\section{$\mathbf{N}$ and $\mathbf{P}$ Fertility and Weed Suppression in Maize}

Long season maize cultivar SC 701, was planted in plots previously under cover crops in the summer seasons of 2009/2010 and 2010/2011. Maize was planted at a spacing of $30 \mathrm{~cm}$ within the row and $90 \mathrm{~cm}$ inter-row, targeting a population of 37000 plants $\mathrm{ha}^{-1}$. Hand held jab planters, which dropped 2-3 seeds, were used and the crop was later thinned to one plant per station at three weeks after planting (3 WAP). Fertilizer application to the maize crop was at a rate of $60 \mathrm{~kg} \mathrm{~N} \mathrm{ha}^{-1}$ with a third of the $\mathrm{N}$ applied as a basal compound fertilizer with an N: P: K ratio of 2:3:4 (30)+ $0.5 \% \mathrm{Zn}$ at planting. The remainder was applied as top dressing with limestone-ammonium nitrate (LAN) $(28 \% \mathrm{~N})$ at 6 WAP. In order to determine the effect of cover crop residues on weeds during the critical phase of weed competition with maize, weed control was only done after 9 WAP. Thereafter, weeds were controlled using Basagran (a.i: thiadiazine $480 \quad \mathrm{~g}^{-1}$ ) applied at $5 \mathrm{~L}^{-1}$. Supplementary overhead irrigation water was applied to all treatments as summarized in Table 1, based on Class A evaporation pan readings. Destructive sampling of weeds in the follow-on maize in 2010/2011 season was done using two randomly placed $0.35 \times 0.35 \mathrm{~m}$ quadrants. All weed biomass present within the quadrant was cut at ground level and oven-dried at $65^{\circ} \mathrm{C}$ to constant mass for dry weight determination. Weed species count in the quadrants was also done in 2010/2011 maize crop at 9 WAP and the weeds were identified following guidelines by Bromilow (1995).

Soil $\mathrm{N}$ and $\mathrm{P}$ measurement was only done in the second season maize crop by collecting soil samples from three depths of 0-20, 20-40 and 40-60 cm at maize planting, V10, R1, denting stage and harvesting which corresponded to $0,6,12,19$ and 24 WAP, respectively. Three soil samples were taken between maize rows in each plot and thoroughly mixed to make a composite sample, which was immediately frozen. Soil inorganic N (ammonium-N plus nitrate-N) was determined after extraction with $2 \mathrm{M} \mathrm{KCl}$ solution (Maynard and Kalra, 1993). Inorganic $\mathrm{P}$ was extracted using $\mathrm{HCl}$ acid and read under a UV-VIS spectrophotometer set at $880 \mathrm{~nm}$ following the Bray 1 method by Okalebo et al. (2002).

Similarly maize $\mathrm{N}$ and $\mathrm{P}$ uptake was measured in the second season by destructive sampling of five maize plants per plot, cutting at their base at each soil sampling. The maize plant samples were oven dried at $65^{\circ} \mathrm{C}$ to constant mass, for dry weight determination, and ground to pass through a $1 \mathrm{~mm}$ sieve. Nitrogen content (\%) was determined by dry combustion using the C/N LECO analyzer (LECO Corporation, 2003). Phosphorus content was determined by wet digestion with $\mathrm{H}_{2} \mathrm{SO}_{4}$ and concentration of $\mathrm{P}$ in the digesting solution was measured using antimony potassium tartrate solution (Okalebo et al., 2002). Total $\mathrm{N}$ and $\mathrm{P}$ uptake by maize was taken as the product of $\mathrm{N}$ and $\mathrm{P}$ concentration multiplied by the maize dry weights. Maize grain yield was taken from a net plot of $2 \times 1.5 \mathrm{~m}$ from the two central rows.

\section{Data Analysis}

All data were subjected to analysis of variance (ANOVA) using Genstat Statistical Package Release 12.1 (Lawes Agricultural Trust, 2009). Data on weed species numbers were transformed using $\log (\operatorname{count}+0.5)$ to normalize the data before subjecting to ANOVA. Treatment means were separated using the least significant difference (LSD) at $p<0.05$. Where transformation was not required, means and least significant differences (LSD) are presented. Where transformation was required, back-transformed means are shown, without presentation of the LSD (Gomez and Gomez, 1984). Correlation analyses were performed to determine the relationship between residue C:N ratio and decomposition rate $(k)$, amount of residue remaining at maize planting and the weed dry weights at 3,6 and 9 WAP in the maize crop. Regression analyses were performed for maize yields against biomass input by the cover crop treatments, soil nutrient status and weed dry weights. 


\section{Results}

\section{Rainfall and Irrigation}

The temperature during the experimental period was comparable to long-term averages (Table 1). The maize received a total of $540 \mathrm{~mm}$ and $542 \mathrm{~mm}$ in both rain and irrigation in 2009/2010 and 2010/2011 summer seasons, respectively.

\section{Biomass Input, C:N Ratio and Decomposition in Litterbag}

The season $\times$ cover crop treatment interaction was significant $(p<0.001)$ with respect to biomass input. In both seasons, biomass input was highest in sole oats followed by the bicultures then sole vetch and weedy fallow had the least (Table 2). In 2009, $90 \%$ oat $+10 \%$ vetch had similar biomass to sole oat, whereas in $2010,70 \%$ oat $+30 \%$ vetch and $90 \%$ oat $+10 \%$ vetch had similar yield to sole oat. Biculture rates of more than $30 \%$ vetch yielded less than sole oat in biomass.

The season $\times$ treatment interaction was not significant ( $p>0.05)$ with respect to $\mathrm{C}: \mathrm{N}$ ratios of cover crops and weed residues. Cover crop treatments differed significantly $(p<0.001)$ in their $\mathrm{C}: \mathrm{N}$ ratios (Table 2). Increasing the vetch component in the mixture, significantly $(p<0.001)$ reduced the $\mathrm{C}: \mathrm{N}$ ratio and vice versa when oat component was increased.

Rate of decomposition of plant material was in the order of weeds $>$ sole vetch $>50 \%$ oat $+50 \%$ vetch $=$ $70 \%$ oat $+30 \%$ vetch $>90 \%$ oat $+10 \%$ vetch $=$ sole oat as shown by the decomposition coefficient $k$ values (Table 2 and Fig. 1). Bicultures significantly increased $(p<0.01)$ the rate of decomposition of plant material compared to that of sole oat, while significantly reducing it $(p<0.001)$ in comparison to that of sole vetch. Amounts of residues remaining at maize planting time differed significantly $(p<0.001)$ among the cover crop treatments and decreased with a decrease in the oat component (Table 2).

\section{Soil Inorganic $\mathbf{N}$ and $\mathbf{P}$}

Soil depth $\times$ cover crop treatment interaction was significant with respect to soil inorganic $\mathrm{N}$ measured at 0 WAP $(p<0.001), 6$ WAP $(p<0.001)$ and 12 WAP $(p<0.01)$ but not at 19 WAP and 24 WAP, where only depth was significant $(p<0.001)$. The greatest variation occurred at 0 WAP and decreased with time up to $19(0-20 \mathrm{~cm}), 12(20-40 \mathrm{~cm})$ and 6 WAP $(40-60 \mathrm{~cm})$ after which there were no differences among treatments.

At maize planting ( $0 \mathrm{WAP})$, sole vetch had the highest inorganic $\mathrm{N}$, which was comparable to that of $50 \%$ vetch $+50 \%$ oat followed by that of $70 \%$ oat $+30 \%$ vetch at all the three soil depths sampled (Fig. 2). Reduced inorganic
$\mathrm{N}$ was observed at $6 \mathrm{WAP}$ compared to $0 \mathrm{WAP}$ in all the treatments (Fig. 2). At 6 WAP, $70 \%$ oat $+30 \%$ vetch, $50 \%$ oat $+50 \%$ vetch and sole vetch had the highest inorganic $\mathrm{N}$ values, which were comparable, while weedy fallow had the least, in the top $20 \mathrm{~cm}$ of the soil. In the $20-40 \mathrm{~cm}$ depth, weedy fallow and $90 \%$ oat $+10 \%$ vetch had the least inorganic $\mathrm{N}$, whilst the rest of the treatments had higher but comparable levels. In the soil depth of $40-60 \mathrm{~cm}$, sole oat, $70 \%$ oat $+30 \%$ vetch and $90 \%$ oat $+10 \%$ vetch had comparable inorganic $\mathrm{N}$, which was significantly higher than the rest of the treatments. At 12 WAP, a slight increase in the inorganic $\mathrm{N}$ was noticed compared to $6 \mathrm{WAP}$, across all treatments. However, $70 \%$ oat $+30 \%$ vetch had the highest amount of inorganic $\mathrm{N}$ followed by $50 \%$ oat $+50 \%$ vetch and weedy fallow had the least in the $0-20 \mathrm{~cm}$ soil depth.

Significant interaction of depth $\times$ cover crop treatment with respect to soil inorganic $\mathrm{P}$ at $0 \mathrm{WAP}$ $(p<0.001)$ and 6 WAP $(p<0.05)$ was observed. However, the interaction and main effects of depth and cover crop treatment were not significant $(p>0.05)$ at 12 WAP and onwards.

At 0 WAP, inorganic $\mathrm{P}$ was highest in sole vetch followed by $90 \%$ oat $+10 \%$ vetch, $70 \%$ oat $+30 \%$ vetch, which had comparable amounts, while weedy fallow had the least in the $0-20 \mathrm{~cm}$ depth (Fig. 3). In the $20-40 \mathrm{~cm}$ depth, all cover crop treatments had significantly higher and comparable $\mathrm{P}$ values than weedy fallow. No treatment differences $(p>0.05)$ were observed in the $40-60 \mathrm{~cm}$ soil depth. At 6 WAP and in the $0-20 \mathrm{~cm}$ depth, $70 \%$ oat + $30 \%$ vetch had the highest amounts of inorganic $\mathrm{P}$ followed by $50 \%$ oat $+50 \%$ vetch, while the rest of the treatments had lower and comparable amounts. No treatment differences $(p>0.05)$ were observed in the $20-40 \mathrm{~cm}$ and 40-60 cm depths. However, soil $\mathrm{P}$ decreased with an increase in depth. While no differences observed at 12, 19 and $24 \mathrm{WAP}$ in soil $\mathrm{P}$ this tended to decrease as the season progressed (Fig. 3).

\section{Maize $N$ and $P$ Uptake}

The $\mathrm{N}$ uptake data showed significant differences among treatments at all the sampling dates (Fig. 4). At 6 WAP, plots previously with sole vetch and $50 \%$ oat $+50 \%$ vetch had the greatest $\mathrm{N}$ uptake, while weedy fallow and sole oat had the least, which were comparable. At 12, 19 and 24 WAP, plots previously with sole vetch, $70 \%$ oat $+30 \%$ vetch and $50 \%$ oat $+50 \%$ vetch had higher $\mathrm{N}$ uptake, while weedy fallow consistently had lower $\mathrm{N}$ uptake levels (Fig. 4). Treatment differences in maize P uptake were only significant at 19 and 24 WAP. At 19 WAP, plot previously with $70 \%$ oat $+30 \%$ vetch had the highest $\mathrm{P}$ uptake of $15.37 \mathrm{~kg} \mathrm{ha}^{-1}$ followed by sole vetch with $14.74 \mathrm{~kg} \mathrm{ha}^{-1}$ and $50 \%$ oat $+50 \%$ vetch with $13.98 \mathrm{~kg} \mathrm{ha}^{-1}$ (Fig. 4). Maize in the former weedy fallow plot had the least uptake of $11.04 \mathrm{~kg} \mathrm{ha}^{-1}$. 
Oat-vetch Cover Crop Effects Residue Decomposition, Weeds and Soil Fertility / Int. J. Agric. Biol., Vol. 17, No. 3, 2015

Table 1: Mean monthly temperatures, rainfall and irrigation at the University of Fort Hare Research Farm from October 2009 to March 2011

\begin{tabular}{lcccccccc}
\hline Months & \multicolumn{3}{c}{ Temperature $\left({ }^{\circ} \mathrm{C}\right)$} & & Rainfall $(\mathrm{mm})$ & \multicolumn{2}{c}{ Irrigation $(\mathrm{mm})$} \\
\cline { 2 - 8 } & $2009 / 2010$ & $2010 / 2011$ & 30 year mean & $2009 / 2010$ & $2010 / 2011$ & 30 year mean & $2009 / 2010$ & $2010 / 2011$ \\
\hline Oct & 18.0 & 17.8 & 17.7 & 56.4 & 60.3 & 60.4 & - & 50.0 \\
Nov & 20.0 & 20.2 & 19.3 & 50.8 & 62.3 & 80.9 & 40.0 \\
Dec & 20.7 & 20.6 & 21.0 & 42.5 & 122.6 & 73.5 & 60.0 & 15.0 \\
Jan & 22.9 & 22.5 & 22.2 & 60.6 & 103.2 & 67.3 & 45.0 & 15.0 \\
Feb & 24.2 & 23.2 & 22.6 & 112 & 40.2 & 66.9 & 30.0 & 30.0 \\
Mar & 23.0 & 20.7 & 21.0 & 32.4 & 63.5 & 63.5 & - \\
\hline
\end{tabular}

Table 2: Biomass input in 2009 and 2010 winter seasons, residue C: $\mathrm{N}$ ratios, decomposition coefficients $(k)$ and residues remaining by the time of planting maize in the 2010/2011 summer season

\begin{tabular}{lccccc}
\hline Cover crop treatment & \multicolumn{2}{c}{ Biomass input $\left(\mathrm{kg} \mathrm{ha}^{-1}\right)$} & Residue C: N ratio & Decomposition coefficient $(k)$ & Residue remaining $\left(\mathrm{kg} \mathrm{ha}{ }^{-1}\right)$ \\
\cline { 2 - 3 } & 2009 & 2010 & & $0.10^{\mathrm{d}}$ & $5028^{\mathrm{a}}$ \\
\hline $100 \%$ oat & $7543^{\mathrm{a}}$ & $8473^{\mathrm{a}}$ & $18.2^{\mathrm{a}}$ & $0.12^{\mathrm{d}}$ & $4246^{\mathrm{b}}$ \\
$90 \%$ oat $+10 \%$ vetch & $7281^{\mathrm{ab}}$ & $8178^{\mathrm{ab}}$ & $14.9^{\mathrm{b}}$ & $0.17^{\mathrm{c}}$ & $3154^{\mathrm{c}}$ \\
$70 \%$ oat $+30 \%$ vetch & $6906^{\mathrm{b}}$ & $8471^{\mathrm{a}}$ & $13.2^{\mathrm{c}}$ & $0.18^{\mathrm{c}}$ & $2331^{\mathrm{d}}$ \\
$50 \%$ oat $+50 \%$ vetch & $6700^{\mathrm{c}}$ & $6548^{\mathrm{c}}$ & $12.1^{\mathrm{d}}$ & $0.23^{\mathrm{b}}$ & $1864^{\mathrm{d}}$ \\
$100 \%$ vetch & $6954^{\mathrm{bc}}$ & $6940^{\mathrm{bc}}$ & $10.0^{\mathrm{e}}$ & $0.31^{\mathrm{a}}$ & $993^{\mathrm{e}}$ \\
Weedy fallow & $3916^{\mathrm{d}}$ & $3292^{\mathrm{d}}$ & $12.1^{\mathrm{d}}$ & $* *$ & $* * 3$ \\
Significance & $* * *$ & $* * *$ & $* * *$ & 0.03 & 539 \\
LSD 0.05 & 440 & 1314 & 0.8 & 8.73 & 10.1 \\
CV $(\%)$ & 8.6 & 10.34 & 4.82 & \\
\hline
\end{tabular}

Means followed by different letters in the same column differ significantly at $p<0.05$

** and*** significant at 0.01 and 0.001 probability level, respectively

Table 3: Residual effects of cover crop treatments on weed dry weights $\left(\mathrm{kg} \mathrm{ha}^{-1}\right)$ at 3,6 and 9 WAP in the follow-on maize crop in the 2010/2011 summer season

\begin{tabular}{llll}
\hline Cover crop treatment & $3 \mathrm{WAP}$ & $6 \mathrm{WAP}$ & $9 \mathrm{WAP}$ \\
\hline $100 \%$ oat & $79^{\mathrm{bc}}$ & $473^{\mathrm{c}}$ & 649 \\
$90 \%$ oat $+10 \%$ vetch & $79^{\mathrm{bc}}$ & $445^{\mathrm{c}}$ & 648 \\
$70 \%$ oat $+30 \%$ vetch & $67^{\mathrm{c}}$ & $426^{\mathrm{c}}$ & 612 \\
$50 \%$ oat $+50 \%$ vetch & $78^{\mathrm{bc}}$ & $550^{\mathrm{b}}$ & 646 \\
$100 \%$ vetch & $88^{\mathrm{b}}$ & $554^{\mathrm{b}}$ & 656 \\
Weedy fallow & $101^{\mathrm{a}}$ & $647^{\mathrm{a}}$ & 741 \\
Significance & $* *$ & $* * *$ & $\mathrm{~ns}$ \\
LSD 0.05 & 13 & 54 & 141 \\
CV $(\%)$ & 8.6 & 5.7 & 6.5 \\
\hline
\end{tabular}

Table 4: Residual effects of cover crop treatments on maize grain yield $\left(\mathrm{kg} \mathrm{ha}^{-1}\right)$ in the $2010 / 11$ summer season

\begin{tabular}{ll}
\hline Treatment & Grain yield $\left(\mathrm{kg} \mathrm{ha}^{-1}\right)$ \\
\hline $100 \%$ oat & $5277^{\mathrm{bc}}$ \\
$90 \%$ oat $+10 \%$ vetch & $5489^{\mathrm{bc}}$ \\
$70 \%$ oat $+30 \%$ vetch & $6368^{\mathrm{a}}$ \\
$50 \%$ oat $+50 \%$ vetch & $5604^{\mathrm{b}}$ \\
$100 \%$ vetch & $5497^{\mathrm{bc}}$ \\
Weedy fallow & $4961^{\mathrm{c}}$ \\
Significance & $* *$ \\
LSD 0.05 & 584 \\
CV $(\%)$ & 5.8 \\
\hline Means followed by different letters in the same column differ \\
significantly at $p<0.05 ; * *$, significant at 0.01 probability level
\end{tabular}

\section{Weed Dry Weights and Species Counts in the Maize Crop}

There were significant differences among cover crop treatments with respect to weed dry weights in the follow-on maize crop at 3 WAP $(p<0.01)$ and 6 WAP $(p<0.001)$ (Table 3), but not at 9 WAP. At 3 WAP, plots previously grown to bicultures were similar and comparable with the $100 \%$ oat treatment but differed significantly in weed biomass to weedy fallow. Only the $70 \%$ oat $+30 \%$ vetch biculture plots had lower weeds than the $100 \%$ vetch plots. At 6 WAP, all cover crop treatments differed significantly from weedy fallow but only treatments with high proportion of oat $(90 \%$ oat $+10 \%$ vetch and $70 \%$ oat $+30 \%$ vetch) were as effective as $100 \%$ oat in suppressing weeds. The $50 \%$ oat $+50 \%$ vetch treatment performed the same as the $100 \%$ vetch. However, weedy fallow plot resulted in the highest weed dry weight values at all the sampling dates. Significant and negative correlations $(p<0.05)$ were observed at $3 \mathrm{WAP}(r=-0.66)$ and $6 \mathrm{WAP}(r=-0.67)$ between amount of residue remaining at maize planting and weed dry weights, but not at 9 WAP $(p>0.05)$. Weed species counts at 9 WAP were not significantly different $(p>0.05)$ among the treatments.

\section{Maize Grain Yield}

The highest maize grain yield was obtained from plots previously under $70 \%$ oat $+30 \%$ vetch which differed significantly $(p<0.01)$ from all other treatments. The $50 \%$ oat $+50 \%$ vetch treatment differed with the weedy fallow but it was the same as the $90 \%$ oat $+10 \%$ vetch, $100 \%$ oat and $100 \%$ vetch treatments. The latter three cover crop treatments were the same as the weedy fallow with respect to maize grain yield (Table 4). Contrast analysis showed that biculturing significantly $(p<0.05)$ increased grain yield 


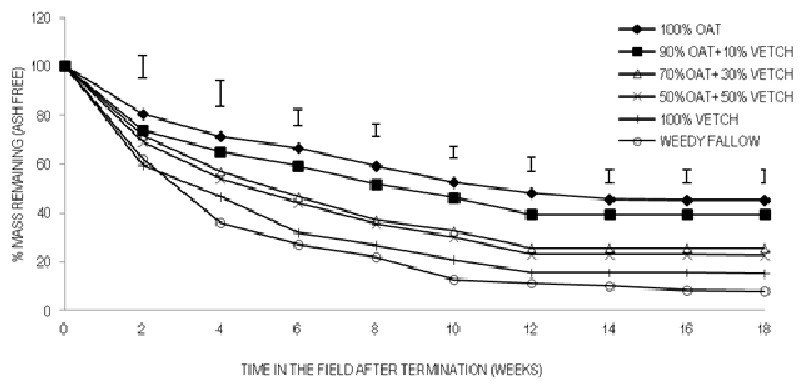

Fig. 1: Effect of cover crop treatments on cover crop residue decomposition in litterbags in the field. Error bars represent $\mathrm{LSD}_{0.05}$
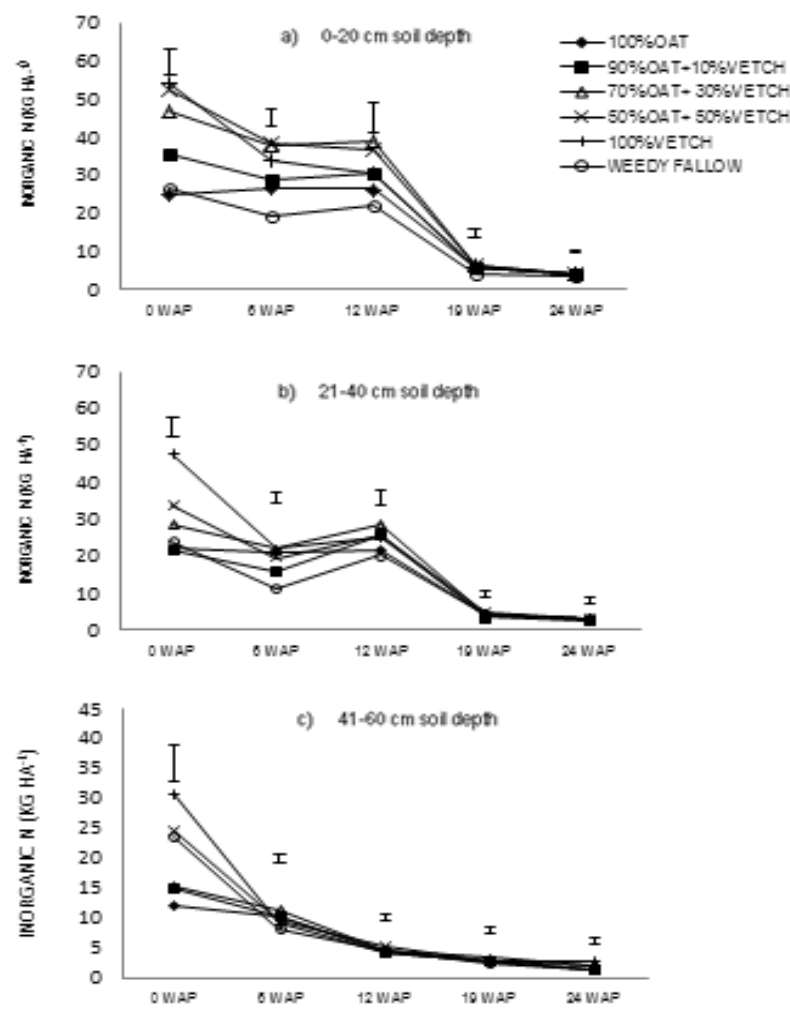

Fig. 2: Residual effects of cover crop treatments on soil inorganic nitrogen in a maize field from soils sampled at 0-20 cm, 21-40 $\mathrm{cm}$ and 41-60 cm. Error bars represent $\mathrm{LSD}_{0.05}$

compared to sole oat but not sole vetch. Biomass at termination of cover crops, weed dry weights at 3 WAP and inorganic $\mathrm{N}$ in $0-20 \mathrm{~cm}$ at maize planting significantly explained maize grain yield realised in the follow-on maize crop (Table 5).

\section{Discussion}

The intermediate decomposition coefficients $(k)$ of the biculture residues were lower than sole vetch and higher
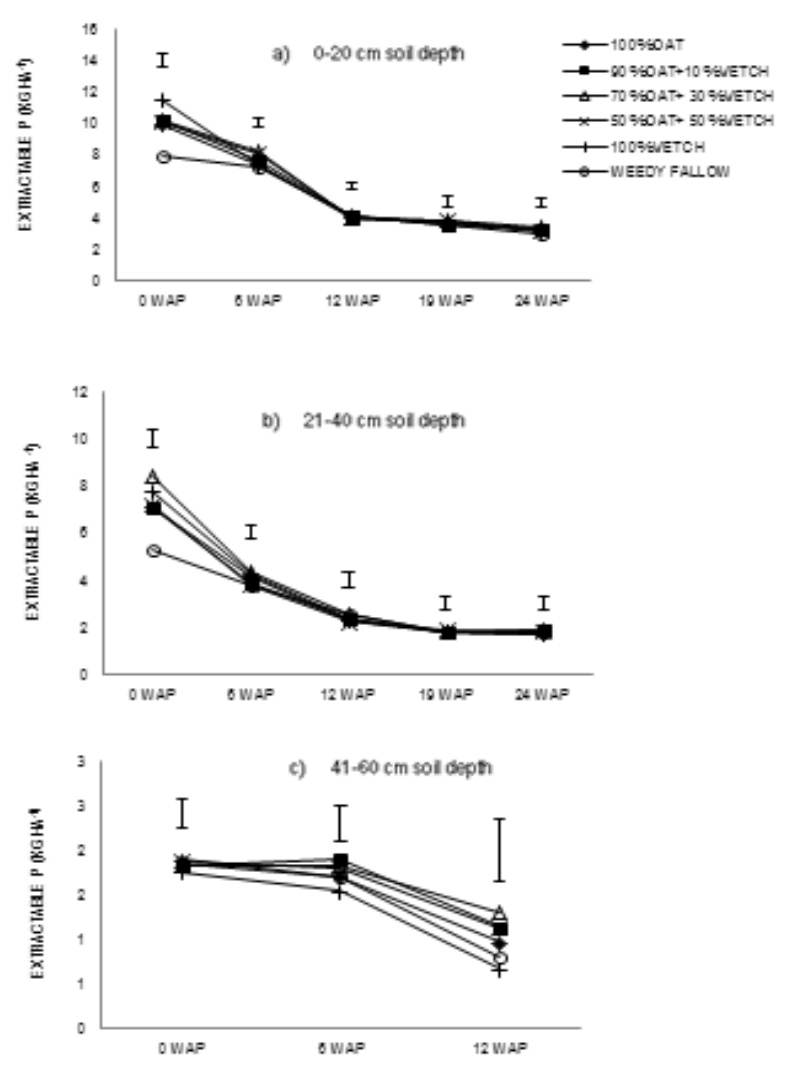

Fig. 3: Residual effects of cover crop treatments on soil inorganic phosphorus in a maize field from soils sampled at $0-20 \mathrm{~cm}, 21-40 \mathrm{~cm}$ and $41-60 \mathrm{~cm}$. Error bars represent LSD $_{0.05}$

than white oat. Ruffo and Bollero (2003) also found intermediate decomposition rates from bicultures of rye and vetch. The decomposition rates could be explained in part by the $\mathrm{C}: \mathrm{N}$ ratios which were in the order; oat $>$ bicultures $>$ vetch. The intermediate decomposition rates by bicultures were explained by Rosecrance et al. (2000) to be the result of the presence of a grass, which moderates the rapidity of decomposition of the legume cover crop. Whilst chemical composition of the residues such as lignin, cellulose and polyphenols were not subject to observation in the current study, white oat is known to have the greatest concentration of the chemicals compared to vetch. Studies by Murungu et al. (2010) under similar conditions observed reduced decomposition rates with an increase in the concentration of lignin and polyphenols.

While the fast degradation of the residues is good for quick nutrient release particularly if synchronized with the peak demand by the follow-on crop, prolonged weed suppression and possibly water conservation by the same residues may be compromised. Persisting residues are particularly attractive as they provide soil cover for extended periods and hence weed suppression (Teasdale $e t$ al., 2007). This was reflected by the significant and negative relationship between the amounts of residue remaining and 
weeds dry weights at $3 \mathrm{WAP}$ and $6 \mathrm{WAP}$ in the maize crop. Residues suppress weed growth by altering light and temperature to the ground as well as providing a barrier to emerging weed seedlings (Teasdale et al., 2007; Dube et al., 2012). The amount of residues remaining at maize planting was a function of the amounts of residues added and their chemical composition ( $\mathrm{C}: \mathrm{N}$ ratio). In this study, incorporating vetch up to $50 \%$ of the mixture resulted in $\mathrm{C}: \mathrm{N}$ ratios that were lower than the $20-25$, the point below which net mineralization will occur. Sole oat had a C:N ratio of 18.2, lower than the reported range for grasses of 25-55 (Starovoytov et al., 2010). In this study the cover crops were terminated earlier, at flowering stage which could explain the lower $\mathrm{C}: \mathrm{N}$ ratios by the sole oat. The findings emphasises the need for smallholder farmers to achieve high and persisting biomass as it is important in suppressing weed growth, a major challenge on their farms.

The soil nutrient levels, which ranged between 25-54 $\mathrm{kg} \mathrm{ha}^{-1}$ and 7-12 $\mathrm{kg} \mathrm{ha}^{-1}$ for inorganic $\mathrm{N}$ and $\mathrm{P}$, respectively, were lower than those observed by Crandall et al. (2005) and Kuo et al. (1996). The difference could be due to incorporation of rye and vetch residues by the researchers, which could have degraded faster, increasing levels of inorganic $\mathrm{N}$ as opposed to the residues left to degrade on the surface as in our study. Furthermore, studies comparing effects of cover crop on soil fertility often produce variable results depending on soil type, climatic conditions, cropping sequence, number of years after initiation of CA, species involved as well as the time of sampling.

The variation in soil inorganic $\mathrm{N}$ and $\mathrm{P}$ levels was a function of the different decomposition rates by the different residues, which were affected by their C:N ratios. Sole vetch, which had higher decomposition coefficient, had higher inorganic $\mathrm{N}$ and $\mathrm{P}$ in the top $40 \mathrm{~cm}$ of the soil compared to that of the bicultures whilst sole oat had lower compared to that of the bicultured treatments. The observed increase in inorganic soil $\mathrm{N}$ and $\mathrm{P}$ in bicultured treatments ( $70 \%$ oat $+30 \%$ vetch and $50 \%$ oat $+50 \%$ vetch) late in the season could be related to the slower rates of decomposition as observed in the litterbag study. This could explain the higher $\mathrm{N}$ and $\mathrm{P}$ uptake by maize plants in these treatments. This view was supported by the higher $\mathrm{N}$ content in the deeper layers of the profile in grazing vetch and the weed fallow plots at maize planting, which could be explained by the higher decomposition rates, resulting in leaching of
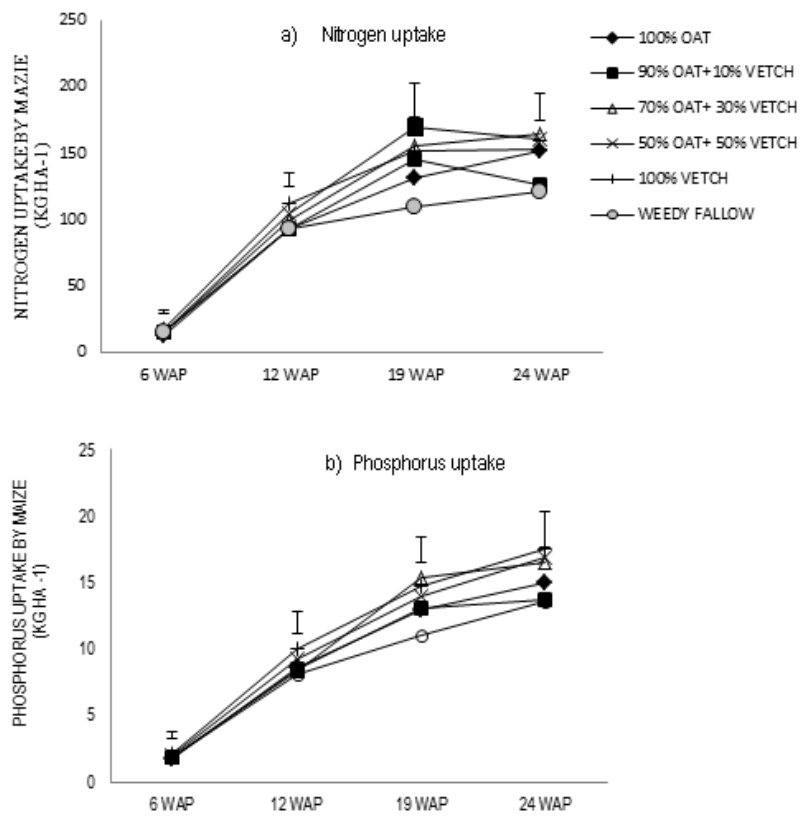

Fig. 4: Residual effects of cover crop treatments on nitrogen and phosphorus uptake by follow-on maize plants from early vegetative to maturity. Error bars represent LSD 0.05

mineralized N (Ranells and Wagger, 1996). The decline in inorganic $\mathrm{N}$ as the season progressed might be attributed the observation to increasing nutrient uptake by maize due to increased root density (Chikowo et al. (2003). The similarities of treatments in terms of inorganic $\mathrm{P}$ in the lower depths of 40-60 cm could be because the nutrient is immobile, resulting in the contribution of the cover crop to be only limited to the top soil, particularly considering that the residues were not incorporated.

The improvement in maize grain yield compared to the weed fallow demonstrated the benefit of cover cropping in rotation with maize. Maize grain yield was in the order of $70 \%$ oat $+30 \%$ vetch $>50 \%$ oat $+50 \%$ vetch $>90 \%$ oat + $10 \%$ vetch $>100 \%$ oat $>$ weed fallow and this could be a function of a number of factors including cover crop biomass and its decomposition rate, resulting in weed suppression and nutrient uptake effects observed in this study. The effects on maize grain yield to cover crop biomass, weed suppression and soil $\mathrm{N}$ improvements.

Table 5: Relationships between various parameters measured in cover crop plots and maize grain yield

\begin{tabular}{|c|c|c|c|}
\hline Variable & Regression equation & $\mathrm{R}^{2}$ value & Significance \\
\hline Cover crop biomass at termination in 2011 & $Y=4910+0.10 x$ & 0.50 & $* *$ \\
\hline Weed biomass at 3 WAP & $Y=7699-26.42 x$ & 0.39 & $* *$ \\
\hline Weed biomass at 6 WAP & $Y=6699-2.24 x$ & 0.21 & ns \\
\hline Inorganic $N(0-20 \mathrm{~cm})$ at maize planting & $Y=4496+18.77 x$ & 0.23 & $*$ \\
\hline Inorganic $\mathrm{P}(0-20 \mathrm{~cm})$ at maize planting & $Y=3823+516 x$ & 0.15 & ns \\
\hline
\end{tabular}

ns, not significant, $*$, ** significant at 0.05 and 0.01 probability level, respectively 


\section{Conclusion}

The practice of biculturing oats and vetch has the potential to solve both weed and soil infertility problems faced by the African smallholder farmers. Further studies are recommended to verify the findings under depleted soils representative of the majority of those on smallholder farms.

\section{Acknowledgements}

This document is an output from a project funded by the Govan Mbeki Research and Development Centre (GMRDC), University of Fort Hare and the National Research Foundation (NRF), South Africa. The views expressed are not necessarily those of the NRF or the GMRDC. The authors also thank the anonymous reviewers, whose comments were valuable in improving this paper.

\section{References}

Bromilow, C., 1995. Problem Plants and Alien Weeds of South Africa, $2^{\text {nd }}$ edition. Briza Publications, Arcadia, South Africa

Chikowo, R., P. Mapfumo, P. Nyamugafata, G. Nyamadzawo and K.E Giller, 2003. Nitrate-N dynamics following improved fallows and maize root development in a Zimbabwean sandy clay loam. Agroforest Syst., 59: 187-195

Clark, A.J., A.M. Decker, J.J. Meisinger and M.S. Mcintosh, 1997. Kill date of vetch, rye, and vetch-rye mixture: I. Soil moisture and corn yield. Agron. J., 89: 434-441

Crandall, S., M. Ruffo and A. Bollero, 2005. Cropping system and nitrogen dynamics under a cereal winter cover crop preceding corn. Plant Soil, 268: 200-219

Dabney, M., J.A. Delgado, J.J. Meisinger, H.H. Schomberg, M.A Liebig, T. Kaspar and J. Mitchell, 2010. Using cover crops and cropping systems for nitrogen management. In: Advances in Nitrogen Management for Water Quality, pp: 230-281. Delgado, J.A. and R.F. Follett (eds.). Soil and Water Conservation Society, Ankeny, USA

Derpsch, R., 2003. South Africa Report, Promotion of conservation agriculture. Project Number TCP/SAF/2902. National Department of Agriculture Final Report. South Africa

Dube, E., C. Chiduza, P. Muchaonyerwa, M. Fanadzo and T.S. Mthoko, 2012. Winter cover crops and fertiliser effects on the weed seed bank in a low-input maize-based conservation agriculture system. S. Afr. J Plant Soil, 29: 195-197

Fanadzo, M., C. Chiduza and P.N.S. Mnkeni, 2009. Investigation of agronomic factors constraining productivity of grain maize (Zea mays L.) at Zanyokwe irrigation scheme, Eastern Cape, South Africa. J. Appl. Biosci., 17: 948-958

FAO, 2008. Conservation Agriculture. http://www.fao.org/ag/ca/1a.html (Accessed on 2 February 2013).

Giller, K.E., E. Witter, M. Corbeels and P. Tittonell, 2009. Conservation agriculture and smallholder farming in Africa: the heretics' view. Field Crop. Res., 114: 23-34

Gomez, K.A. and A.A. Gomez, 1984. Statistical Procedures for Agricultural Research, $2^{\text {nd }}$ edition. Wiley Inter-science publication, Singapore

IUSS Working Group WRB, 2006. World Reference Base for Soil Resources. World Soil Resources Report No. 103. FAO, Rome

Jordan, N.R., J. Zhang and S. Huerd, 2000. Arbuscular-mycorrhizal fungi: Potential roles in weed management. Weed Res., 40: 397-400
Kumar, V., D.C. Brainard and R.R. Bellinder, 2008. Suppression of powell amaranth (Amaranthus powellii), shepherds-purse (Capsella bursapastoris) and corn chamomile (Anthemis arvensis) by buckwheat residues: Role of nitrogen and fungal pathogens. Weed Sci., 56: 271-280

Kuo, S., U.M. Sainju and E.J. Jellum, 1996. Winter cover cropping on nitrogen mineralization and corn yields. Soil Biol., 22: 310-317

Lawes Agricultural Trust, 2009. Genstat Release, $12^{\text {th }}$ edition. VSN International, Helmel, Hempstead, Hertfordshire, UK

LECO Cooperation, 2003. Truspec Carbon and Nitrogen Determinator. Leco Cooperation 3000. Lakeview Avenue St Joseph, Miami, USA

Mandiringana, O.T., P.N.S. Mnkeni, Z. Mkile, W. van Averbeke, E. van Ranst and H. Verplancke, 2005. Mineralogy and fertility status of selected soils of the Eastern Cape Province, South Africa. Commun Soil Sci. Plant. Anal., 36: 2431-2446

Maynard, D.G. and Y.P Kalra, 1993. Nitrate and Exchangeable Ammonium Nitrogen. In: Soil Sampling and Methods of Analysis, Canadian Society of Soil Science, pp: 25-38. Carter, M.R. (ed.). Lewis Publishers, Boca Raton, Florida, USA

Murungu, F., C. Chiduza and P. Muchaonyerwa, 2010. Decomposition, nitrogen and phosphorus mineralization from winter-grown cover crop residues and suitability for a smallholder farming system in South Africa. Nutr Cycl Agroecosys, 89: 115-123

Murungu, F., C. Chiduza and P. Muchaonyerwa, 2011. Mulch effects on soil moisture productivity in warm-temperate climate of South Africa. Soil Till. Res., 112: 58-65

Muzangwa, L., C. Chiduza and P. Muchaonyerwa, 2012, Biomass production, weed suppression, nitrogen and phosphorus uptake in white oat (Avena sativa L.) and grazing vetch (Vicia dasycarpa L.) cover crop bicultures under an irrigated no-till system. S. Afr. J. Plant Soil, 29: 135-141

Nicolardot, B., S. Recous and B. Mary, 2001. Simulation of C and N mineralization during crop residue decomposition: a simple dynamic model based on the C:N ratio of the residues. Plant Soil, 228: 83-103

Okalebo, J.R., K.W. Gathua and P.L. Woomer, 2002. Laboratory Methods of Soil and Plant Analysis: Working Manual, $2^{\text {nd }}$ edition. Nairobi, Kenya: TSBF-CIAT and SACRED Africa

Ranells, N.N. and M.G. Wagger, 1996. Nitrogen release from grass and legume cover crop monocultures and bicultures. Agron. J., 88: 777-782

Rosecrance, R.C., G.W. McCarty, D.R. Shelton and J.R. Teasdale, 2000 Denitrification and $\mathrm{N}$ mineralization from hairy vetch $(V$. villosa) and rye (Secale cereale) cover crop monocultures and bicultures. Plant Soil, 227: 283-290

Ruffo, L. and A. Bollero, 2003. Residue decomposition and prediction of carbon and nitrogen release rates based on biochemical fractions using principal-component regression. Agron. J., 95: 1034-1040

Sainju, U.M., W.F. Whitehead and B.P. Singh, 2005. Biculture legumecereal cover crops for enhanced biomass yield, carbon, and nitrogen Agron. J., 97: 1403-1412

Soil Classification Working Group, 1991. Soil Classification: A Taxonomic system for South Africa. Memoirs of the Agricultural Natural Resources of South Africa, No. 15. Department of Agriculture Development, Pretoria, South Africa

Starovoytov, A., R.S. Gallagher, K.R. Jacobsen, J.P. Kaye and B. Bradley, 2010. Management of small grain residues to retain legume-derived nitrogen in corn cropping systems. Agron. J., 102: 895-903

Teasdale, J.R., 1996. Contributions of cover crops to weed control management in sustainable agriculture systems. J. Agric. Prod., 9 475-479

Teasdale, J.R., L.O. Brandsaeter, A.Calegari, and N.F. Skora, 2007. Cover crops and weed management. In: Non-chemical Weeds Management pp: 49-64. Upadyaya, M.K. and R.E. Blackshaw (eds.). CABI International, Wallingford, UK

(Received 20 March 2013; Accepted 19 August 2014) 